\subsection{3 : $539.319: 539.43 .014 .12$}

[13]歯車リムの菌元疲れ強さ [G. Lechner, Konstruktion, 1967-2, Jg. 19, Ht. 2, S. 41 47, 図 15, 表 4] 歯車の直径が $600 \mathrm{~mm}$ ぐらいになると, 歯 切りしたりムをホイールに焼きばめまたは圧入して使 うことが多い。このときりムには焼きばめによる予忍 力が生じ，歯元疲れ強さを減少させる. そこでモジュ 一ル 8, ピッチ円值径 $480 \sim 1120 \mathrm{~mm}$ の歯車りムに つきこれを実験している，焼きばめ応力に相当するも のとしては，リムに $1 / 50$ テーパの心棒を圧入して予 応力を発生させ，そのままで歯をパルセータにはさ み, 疲れ試験した。歯元疲れ強さは予応力とともに低 下し, $12 \sim 20 \mathrm{kp} / \mathrm{mm}^{2}$ の予応力範囲では調質鋼で 70〜 85\%，浸炭焼入れ䥡で 60〜 70\% に低下する．調質鋼 でそれほど下がらないのは切欠き感度が低いためと説 明される。リムの厚さは，燒きばめ応力を変化させる 限りにおいて歯元強さに影響する。このほか、リムの 歯元強さには，焼入れ方法による焼入れ深さの相違が 影響するとともに異なる歯車材質, 熱処理の影響, さ らに歯元のショットピーニングの影響, 研削割れの影 響もあることをそれぞれ実験している．歯底の仕上げ あらさの影響も述べてある。 [高田潤]

621.833.3 : 620.178 .16

※[14]ハイポイド歯車の摩耗および焼付限界荷重 [G. Niemann u. K. Langenbeck, $V D I-Z, 1967-2$, Bd. 109, Nr. 6, S. 213 225, 図 29, 表 7] 自動 車用ハイポイド歯車をそのまま試験歯車としている. 歯車の諸元は, 平均ピッチ円半径 : ピニオン 48.20 $\mathrm{mm}$ メリングギヤ $147.42 \mathrm{~mm}$, 歯数 : $10 \times 41$ 枚, 歯 幅 : $32.2 \times 28.0 \mathrm{~mm}$, オフセット : $25.4 \mathrm{~mm}$, 材質 : $20 \mathrm{MoCrS} 4 \mathrm{E}$ 表面硬化である。試験歯車は静止した 状態で負荷をかける動力循環式であり，2組の八イポ イド歯車と 1 対のはすば歯車から構成されている. ピニオンの回転数は $6000 \mathrm{rpm}$ まで, 馬力は $13 \mathrm{PS}$ (1500 rpm)〜503 PS（6000 rpm）である。潤滑油は 21 種類も使っているが大部分は SAE 90 のハイボド 油に近いものである.しかし比較のため添加剂のはい っていない鉱油 4 種類についても試験している. 限界 荷重としては，摩耗量に対するむのおよび焼付けに対 するものがある．実験歯車では $1000 \mathrm{rpm}$ 以下におい ては焼付かず摩耗に対する限界荷重が存在し，1000 $\mathrm{rpm}$ 以上では焼付けに対する限界荷重がある．適当 になじみ運転をすれば焼付荷重が約 2 倍になることも ある. 周速が $2.5 \mathrm{~m} / \mathrm{s}$ 以下になるとピニオンの菌面に 波うち（Rippling）が生ずることがある．EP 油より 純鉣油のほうが波うちを生じにくい. [石橋彰]

\subsection{3-72 : $621.89: 629.19$}

〔15]宇宙の真空をシミュレートしたふん囲気にお ける歯車の運転 [M.F. Federline \& C.E. Vest, Lubric. Engng., 1967-4, Vol. 23, No. 4, p. 134 144, 図 12, 表 4]。今までの宇宙工学においては, 機械の摩擦部分には普通の潤滑剂を密封状態で使用す るという方針であった。しかし人工衛星もだんだん長 寿命が要求されるようになったので密封性能の低下が 問題になってきた。これに対する根本的対策は，真空 中で運転可能な潤滑材や潤滑方法を研究することであ る. 本論文ではつぎのような 2 種類の実験を行なって
いる. (1) $10^{-8} \mathrm{mmHg} の$ 真空中における計器用歯車の 無負荷運転 (3600 rpm で 500 時間). 材質はステン レス，アルミニウム合金およびプラスチックである. 歯車はピッチ径 1 in と 1.5 in の組合せであり, 歯の 大きさは DP 24,48,80の 3 種類である. (2) 動力循 環式歯車試験機による負荷試験。歯車は DP 48 の歯 数 $55 \times 56$ の組合せである.これらの試験から，今ま で真空中で有望だと考えられていた $\mathrm{MoS}_{2}$ の歯面への コーティングは無負荷に近いときにのみ有効であるこ とがわかった．荷重がかかった場合は常に固体潤滑剤 を補給する必要がある。たとえば，潤滑性能のある材 料（MoGITf）で作ったアイドラをかみあわせる。 ま たころがり軸受のリテイナーも MoGITf で作らねば 軸受のほうが歯車より先にこわれる。[石橋彰]

\section{$621.833: 621.891$}

[16]歯車の潤滑 [E.S. Reynolds, Lubric. Engng., 1967-5, Vol. 23, No. 5, p. 187〜192, 図 10, 表 1]歯車の潤滑における基本的問題およびそれに 対する対策を述べている，油浴潤滑においては，歯車 の回転中における油面をよく観察して静止時における 油の量をきめる. 圧力潤滑の場合は压力計より流量計 または油の流れを見ることのほうがたいせつである. 一般に，歯面に損傷が起こった場合には極圧性の高い $\mathrm{EP}$ 潤滑油を要求しがちであるが，かようなときにも 潤滑油の使用法および使用条件を再検討すれば，それ ほど極圧性の高い潤滑油は必要でない場合が多い，潤 滑油の中に水分やごみがはいらないように特に注意す る必要がある. 歯車箱の形に対する考慮とともに, 歯 車箱の空気と外気の間は乾燥材のつまった通路により 連絡する。また，歯車の損傷の原因としてつぎの 5 項 目をあげおのおのについての奏例を写真で示すととも に，その損傷に対する対策についても述べている.（1) 加工後の歯面のあらさ，(2) 潤滑油の中の異物，(3) ボ ルトや鉄片などの異物のかみ込み，(4) 材料の疲れ(5) 潤滑油の不足. 一般にはこの五つの原因の中のいくつ かが重なって損㑺が起こることが多い.

\section{[石橋彰]}

\subsubsection{7}

[17]強制的にあるいは周期的に起こされたうすの Breakdown について [T. Sarpkaya, ASME Paper, No. 66-WA/FE-7, 1966-11, pp. 7, 図 12] 台風, たつ巻，核然料ロケット，MHD 発電あるいは流体素 子などの解明ないしは開発研究に際し，うずの詳細な 挙動特にその Breakdownの詳細な挙動の解明が要請 される.この本報では，2個のチャンバを，しぼり水 路, 平行水路, 拡大水路で連結した, いわゆる Vortex Tube（全部が透明有機ガラス製）の下流側チャ ンバ内で，流入うず流の反方向のうず運動，あるいは 周期的なうず運動を与えて，人為的にうずの Breakdown を起こさせることに成功し，ついでこの Breakdownの詳細の挙動を観測している，そして「うずの Breakdown がおこると，その近傍の静压が急激に低 下し，激しい騒音が発生し，流れはほぼ軸方向流れと なる」, 「所与の上下流側チャンバ内圧の状態に対し て，まったく相異なる二つの流れの状態（たとえば抗 力係数も二つ）が存在する」などを明らかにした。な 